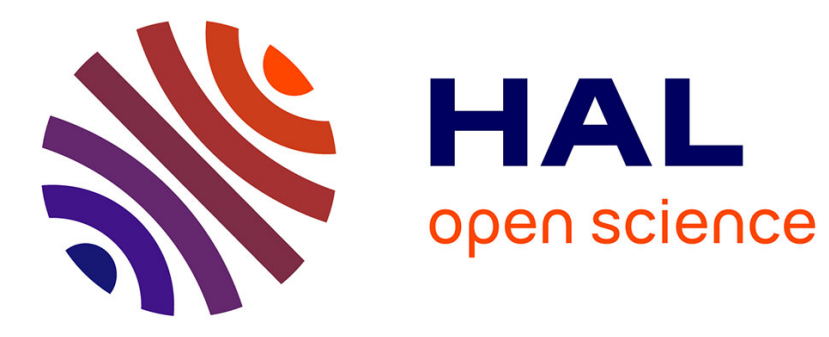

\title{
An Insight into the Structure of Model Germaphosphaallenes
}

\author{
Ioan Silaghi-Dumitrescu, P. M. Petrar, G. Nemes Nemes, J. Escudiéb, H.
}

Ranaivonjatovob

\section{To cite this version:}

Ioan Silaghi-Dumitrescu, P. M. Petrar, G. Nemes Nemes, J. Escudiéb, H. Ranaivonjatovob. An Insight into the Structure of Model Germaphosphaallenes. Molecular Physics, 2009, 107 (08-12), pp.1161-1167. 10.1080/00268970902780288 . hal-00513258

\section{HAL Id: hal-00513258 \\ https://hal.science/hal-00513258}

Submitted on 1 Sep 2010

HAL is a multi-disciplinary open access archive for the deposit and dissemination of scientific research documents, whether they are published or not. The documents may come from teaching and research institutions in France or abroad, or from public or private research centers.
L'archive ouverte pluridisciplinaire HAL, est destinée au dépôt et à la diffusion de documents scientifiques de niveau recherche, publiés ou non, émanant des établissements d'enseignement et de recherche français ou étrangers, des laboratoires publics ou privés. 


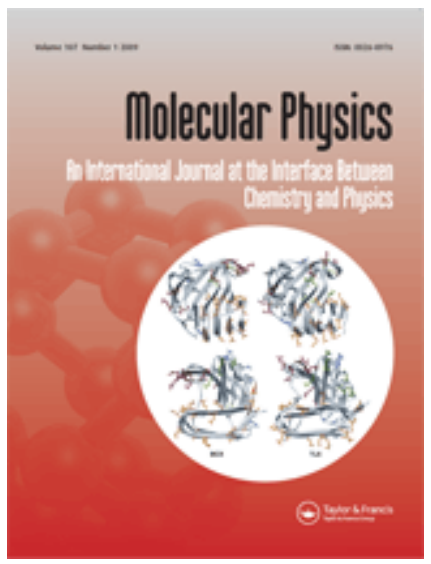

\section{An Insight into the Structure of Model Germaphosphaallenes}

\begin{tabular}{|r|l|}
\hline Journal: & Molecular Physics \\
\hline Manuscript ID: & TMPH-2008-0403.R1 \\
\hline Manuscript Type: & Special Issue Paper - Fritz Schaefer \\
\hline Date Submitted by the & 25-Jan-2009 \\
\hline Complete List of Authors: & $\begin{array}{l}\text { Silaghi-Dumitrescu, Ioan; Universitatea Babes-Bolyai, Department } \\
\text { of Chemistry } \\
\text { Petrar, P. M.; Babes-Bolyai University } \\
\text { Nemes, G. Nemes; Babes-Bolyai University } \\
\text { Escudiéb, J.; Hétérochimie Fondamentale et Appliquée, (UMR CNRS } \\
\text { 5069) } \\
\text { Ranaivonjatovob, H.; Hétérochimie Fondamentale et Appliquée, } \\
\text { (UMR CNRS 5069) }\end{array}$ \\
\hline Keywords: & phosphagermaallenes, B3LYP, CCSD, MP4, theoretical study \\
\hline
\end{tabular}

\section{(5) SholaroNE \\ Manuscript Central}




\title{
An Insight into the Structure of Model Germaphosphaallenes
}

\author{
P. M. Petrar ${ }^{\mathrm{a}, \mathrm{b}}$, G. Nemes ${ }^{\mathrm{a}}$, I. Silaghi-Dumitrescu ${ }^{* a}$, J. Escudie ${ }^{\mathrm{b}}$, H. Ranaivonjatovo ${ }^{\mathrm{b}}$ \\ ${ }^{a}$ Babes-Bolyai University, Cluj-Napoca, Romania; ${ }^{b}$ Hétérochimie Fondamentale et Appliquée Université \\ Paul Sabatier, Toulouse, France
}

The geometries of all possible isomers of the model compound $\mathrm{H}_{2} \mathrm{Ge}=\mathrm{C}=\mathrm{PH}$ were optimized at the B3LYP/6-31G(d,p) level of the theory. The calculation were repeated at higher correlated methods with similar results and for the the isomers of the methyl-substituted phosphagermaallene $\mathrm{MeP}=\mathrm{C}=\mathrm{GeMe}_{2}$. As another way to stabilise the $\mathrm{P}=\mathrm{C}=\mathrm{Ge}$ unit consists in the use electronic effects, a NBO study was carried out in order to identify the influence that the nature (electropositive or electronegative) of several substituents would have on the strength of the $\mathrm{C}=\mathrm{Ge}$ bond. Model compounds $\mathrm{HP}=\mathrm{C}=\mathrm{GeR}_{2}$ and $\mathrm{HP}=\mathrm{C}=\mathrm{GeRR}$ ' were investigated $\left(\mathrm{R}=\mathrm{BH}_{2}, \mathrm{CH}_{3}, \mathrm{SiH}_{3}, \mathrm{NH}_{2}, \mathrm{OMe}, \mathrm{F} ; \mathrm{R}^{\prime}=\mathrm{H}\right)$. It was found that the main interaction contributing to the weakening of the $\mathrm{C}=\mathrm{Ge}$ bond is a transfer of electron density from the lone pair of the phosphorus atom to the molecular antibonding orbital localized on the $\mathrm{Ge}-\mathrm{C}$ bond.

Keywords: phosphagermaallenes, B3LYP, CCSD, MP4, theoretical study

\section{Introduction}

The chemistry of allene analogues of group 14 elements has been in the focus of the scientific community for more than three decades, since the synthesis of the first silaallene by Brook et alter [1].Our group has been interested mainly in the synthesis, characterizations and reactivity of phosphaallenes in which one of the carbon atom is formally replaced with heavy group 14 elements, like Si, Ge and Sn [2-4].

A general synthetic route towards phosphagermaallene has been established by our group [3] and it includes the dehalogenation of 2,3-dihalo-1-phospha-3-germa-1-propenes by means of a lithium reagent. While several precursors of this type have been synthesized [5, 6 ], the choice of the appropriate organic groups on both the phosphorus and the germanium atoms plays an important role in the outcome of the reaction, as it has been shown by us previously $[7,8,9]$.

A transient phosphagermaallene [8] has been evidenced and the synthesis of the first stable phosphagermaallene, Mes* $\mathrm{P}=\mathrm{C}=\mathrm{Ge}(t \mathrm{Bu})(\mathrm{Tip}) \quad\left(\mathrm{Mes}^{*}=2\right.$, 4, 6-tri-tert-butyl-phenyl, Tip $=$ 2, 4, 6-tri-iso-propyl-phenyl) has been carried out recently bu our group [9]. These compounds have been characterized through the usual spectroscopic methods (NMR, IR), but their instability makes computational chemistry a useful tool in the study of their structure and properties, providing the means to investigate them. However, there is only a limited number of papers dealing with theoretical aspects of phosphagermallenes chemistry. Thus, Escudié et.al. rationalized [8] the dimerization outcome of Mes* $\mathrm{P}=\mathrm{C}=\mathrm{GeMe}_{2}$. Their RHF study shows that, the

\footnotetext{
*Corresponding author. Email : isi@chem.ubbcluj.ro
} 
head-to-head dimerization of two $\mathrm{Ge}=\mathrm{C}$ bonds is favoured, in contrast with the experimentally observed formation of four-atom rings from head-to-tail dimerization involving two double $\mathrm{Ge}=\mathrm{C}$ bonds or a head-to-tail $\mathrm{P}=\mathrm{C}$ and a $\mathrm{Ge}=\mathrm{C}$ dimerization (forming new $\mathrm{P}-\mathrm{C}$ and $\mathrm{Ge}-\mathrm{C}$ bonds) [8]. Note however that the most important calculated difference in energy between the head-to head and head-to-tail dimers was around $24 \mathrm{~kJ} / \mathrm{mol}$. Due to the experimental use of very bulky mesityl (2,4,6-tri-methyl-phenyl) and supermesityl groups, the discrepancy with the model calculations is not surprising since the large steric hindrance of substituents disfavor the head-to-head dimers.

In the present work, a theoretical study on model compounds of phosphagermaallenes has been carried out, in order to further characterize such derivatives and also to rationalize the small number of such derivatives described to date.

\section{Results and discussions}

\section{II.1. Structural minima of model 1-3-phosphagermaallenes - a B3LYP/6-31G(d,p) study}

The geometries of all possible isomers of the model compound $\mathrm{PCGeH}_{3}$ were optimized at the B3LYP/6-31G(d,p) [10-13] level of the theory, using the Spartan package of programs [14]. A vibrational analysis was also carried out in order to ensure that all the geometries found correspond to minima. The triplet state of the phosphagermaallene was also investigated in order to see whether the preference for the single state is kept while going from $>\mathrm{Ge}=\mathrm{C}<$ to $>\mathrm{Ge}=\mathrm{C}=\mathrm{P}-$ skeletons. The energy data and results relevant geometrical parameters are given in Table 1.

Table 1. Calculated B3LYP/6-31G(d,p) energies relative to IX $(\mathrm{kJ} / \mathrm{mol})$ and geometrical parameters for $\mathrm{HP}=\mathrm{C}=\mathrm{GeH}_{2}$ isomers (total energy of $\mathbf{I X}$ is -2458.00001 a.u.)

\begin{tabular}{|c|c|c|c|c|c|}
\hline Molecule & $\begin{array}{c}\mathrm{HP}=\mathrm{C}=\mathrm{GeH}_{2} \\
\text { I }\end{array}$ & $\begin{array}{c}\mathrm{HP}=\mathrm{C}=\mathrm{GeH}_{2} \\
\mathbf{I}_{\mathbf{t}} \text { (triplet state) }\end{array}$ & Molecule & $\begin{array}{c}\mathrm{P} \equiv \mathrm{C}-\mathrm{GeH}_{3} \\
\text { II }\end{array}$ & 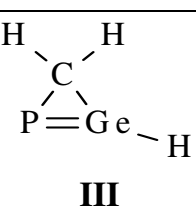 \\
\hline $\begin{array}{c}\text { Relative energy } \\
\text { Ge-C }(\mathrm{pm}) \\
\mathrm{P}-\mathrm{C}(\mathrm{pm}) \\
\mathrm{Ge}-\mathrm{C}-\mathrm{P}\left(^{\circ}\right) \\
\end{array}$ & $\begin{array}{c}195.14 \\
177.9 \\
164.1 \\
156.71 \\
\end{array}$ & $\begin{array}{c}285.10 \\
186.8 \\
1.650 \\
159.18 \\
\end{array}$ & $\begin{array}{c}\text { Relative energy } \\
\text { Ge-C (pm) } \\
\text { P-C }(\mathrm{pm}) \\
\text { Ge-C-P }\left(^{\circ}\right)\end{array}$ & $\begin{array}{c}65.28 \\
192.2 \\
155.3 \\
179.81 \\
\end{array}$ & $\begin{array}{c}126.25 \\
195.3 \\
198.8 \\
65.002 \\
\end{array}$ \\
\hline Molecule & 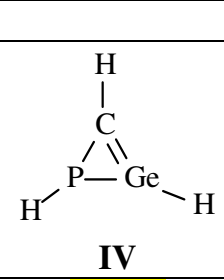 & $\begin{array}{c}\mathrm{HP}=\mathrm{Ge}=\mathrm{CH}_{2} \\
\mathbf{v}\end{array}$ & Molecule & $\begin{array}{c}\mathrm{H}_{2} \mathrm{P}-\mathrm{C} \equiv \mathrm{GeH} \\
\mathbf{V I}\end{array}$ & 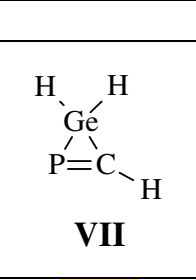 \\
\hline $\begin{array}{c}\text { Relative energy } \\
\text { Ge-C (pm) } \\
\text { P-Ge (pm) } \\
\text { P-Ge-C }\left(^{\circ}\right)\end{array}$ & $\begin{array}{c}104.59 \\
198.9 \\
3.109 \\
29.427\end{array}$ & $\begin{array}{c}110.50 \\
179.6 \\
214.9 \\
150.00\end{array}$ & $\begin{array}{c}\text { Relative energy } \\
\text { Ge-C (pm) } \\
\text { P-C (pm) } \\
\text { Ge-C-P }\left(^{\circ}\right)\end{array}$ & $\begin{array}{c}228.00 \\
180.9 \\
167.0 \\
178.13 \\
\end{array}$ & $\begin{array}{c}90.74 \\
192.4 \\
168.3 \\
79.9 \\
\end{array}$ \\
\hline
\end{tabular}


Thus, the following trend among the relative energies of isomers of $\mathrm{H}_{3} \mathrm{PCGe}$ is observed (Figure 1):

Figure 1. Relative energies (compared to the series minimum IX) of $\mathrm{H}_{3} \mathrm{PCGe}$ isomers

Unexpectedly, the most stable isomer is $\mathbf{I X}$, containing the $\mathrm{P} \equiv \mathrm{Ge}$ triple bond. This comes as a surprise, considering that the instability of multiple bonded germanium derivatives usually increases with the degree of unsaturation, and the isomer containing the $\mathrm{P}=\mathrm{Ge}$ bond is thermodynamically less stable than IX. In fact, our results are in agreement with previous calculations data on organometallic compounds, where phosphorus-germanium triple bonds are computed to be energetically more favored than the germanium-phosphorus double bonds [15, 16]. Electronegative substituents on the germanium atom increase the strength of the triple bond, while those with lower electronegativity weaken it. The reason for which triple bonded germanium compounds are so scarce (and there are no known derivatives containing the $\mathrm{P} \equiv \mathrm{Ge}$ unit reported up to date) must be of kinetical nature; as the use of bulky substituents providing a proper steric protection could lead to the isolation of such derivatives.

Since experimentally we start from the $\mathrm{P}=\mathrm{C}-\mathrm{Ge}$ skeleton to synthesize 1-3phosphagermaallenes, we were more interested in the isomers containing the P-C-Ge sequence. The phosphagermirene IV is theoretically more likely to form than the phospagermaallene $\mathbf{I}$, but no such compound has been previously reported so far. The difference of about $83.74 \mathrm{~kJ} / \mathrm{mol}$ between the energies of $\mathbf{V}$ and $\mathbf{I}$ can be easily covered by the ring opening of the cycle to afford the linear structure.

From all the model-compounds given in Table 1, only VII has a precedent [17] in the literature to be characterized by X-ray crystallography (VIIa), and the present DFT method affords very close geometrical parameters (see Scheme 1), indicating that this computational method is accurate enough in describing such derivatives. 

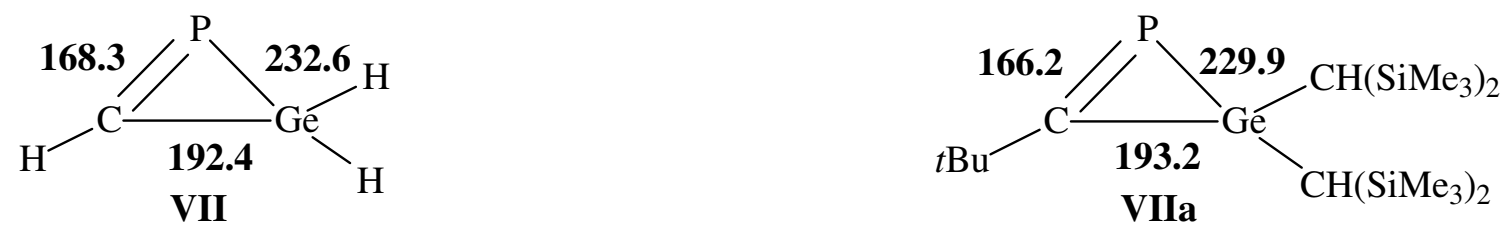

Scheme 1. Bond lengths for VII (calculated) and VIIa (obtained from X-ray data)

The bent geometry obtained for $\mathbf{I}$ is not surprising for such compounds, since heavier group 14 elements are known to prefer a bent structure when involved in multiple bonding [18]. This is in sharp contrast however with the geometry of $\mathrm{H}_{2} \mathrm{C}=\mathrm{C}=\mathrm{CH}_{2}$ allene and heavier analogues resulted by substitution of carbon for silicon, or germanium $\left(\mathrm{H}_{2} \mathrm{Si}=\mathrm{Si}=\mathrm{SiH} 2, \mathrm{H}_{2} \mathrm{Ge}=\mathrm{Ge}=\mathrm{GeH}_{2}\right.$, $\mathrm{H}_{2} \mathrm{Si}=\mathrm{C}=\mathrm{GeH}_{2}, \mathrm{H}_{2} \mathrm{Ge}=\mathrm{C}=\mathrm{GeH}_{2}$ ) which are all optimized to a linear skeleton at the B3LYP/6$31 \mathrm{G}(\mathrm{d})$ method. A molecular orbital analysis of $\mathbf{I}$ reveals that the frontier orbitals have a pronounced antibonding character between the phosphorus and carbon atom in the $\mathrm{P}=\mathrm{C}=\mathrm{Ge}$ unit. The HOMO is mainly localized on the $\mathrm{Ge}=\mathrm{C}$ double bond (Figure 2).

Figure 2. $\mathrm{HOMO}$ (a) and LUMO (b) orbitals of $\mathrm{H}_{2} \mathrm{Ge}=\mathrm{C}=\mathrm{PH} \mathbf{I}$

The same shapes of the frontier orbitals are also found for all the other isomers, the HOMO being mainly localized on the Ge-C bond, while the LUMO has an even more pronounced antibonding character (with three nodal planes) and is localized on the P-C fragment. The HOMO-LUMO separation for $\mathbf{I}$ is more than $4 \mathrm{eV}$. This gap is smaller for the cyclic structures III and IV (3 eV), but increases again for VII, which indicates that the isolation of VIIa is partially due to its smaller kinetical liability compared to the other isomeric rings. The use of sterically hindering substituents on the germanium and phosphorus atoms should afford the stabilization needed for the linear structure. With this in mind, we have slightly increased the steric congestion on the P-C-Ge unit, performing calculations on the isomers of the model phosphagermaallene $\mathrm{MeP}=\mathrm{C}=\mathrm{GeMe}_{2}$ at the same DFT level. The results are given in Table 2.

Table 2. Calculated $\mathrm{B} 3 \mathrm{LYP} / 6-31 \mathrm{G}(\mathrm{d}, \mathrm{p})$ parameters for $\mathrm{MeP}=\mathrm{C}=\mathrm{GeMe}_{2}$ isomers. Energies $(\mathrm{kJ} / \mathrm{mol}$ are given relative to lowest calculated total energy for isomer II (-2575.95922 a.u.).

\begin{tabular}{|c|c|c|c|c|c|}
\hline Molecule & $\mathbf{I}-\mathrm{Me}_{3}$ & $\mathbf{I}_{\mathbf{t}}-\mathbf{M e}_{3}$ (triplet) & Molecule & II-Me $_{3}$ & III-Me $_{3}$ \\
\hline Relative energy & 137.60 & 230.95 & Relative energy & 0.00 & 110.54 \\
\hline $\mathrm{Ge}-\mathrm{C}(\mathrm{pm})$ & 177.1 & 188.3 & $\mathrm{Ge}-\mathrm{C}(\mathrm{pm})$ & 194.2 & 196.8 \\
\hline $\mathrm{P}-\mathrm{C}(\mathrm{pm})$ & 163.8 & 164.6 & $\mathrm{P}-\mathrm{C}(\mathrm{pm})$ & 155.6 & 201.6 \\
\hline Ge-C-P $\left(^{\circ}\right)$ & 167.478 & 157.945 & Ge-C-P $\left(^{\circ}\right)$ & 179.837 & 64.457 \\
\hline Molecule & IV-Me & $\mathrm{V}-\mathrm{Me}_{3}$ & Molecule & $\mathrm{VI}-\mathrm{Me}_{3}$ & VII-Me $_{3}$ \\
\hline
\end{tabular}




\begin{tabular}{|c|c|c|c|c|c|}
\hline Relative energy & 74.48 & 115.44 & Relative energy & 174.95 & 35.37 \\
\hline $\mathrm{Ge}-\mathrm{C}(\mathrm{pm})$ & 199.7 & 187.4 & $\mathrm{Ge}-\mathrm{C}(\mathrm{pm})$ & 183.4 & 193.3 \\
\hline $\mathrm{P}-\mathrm{Ge}(\mathrm{pm})$ & 3.070 & 217.6 & $\mathrm{P}-\mathrm{C}(\mathrm{pm})$ & 164.2 & 169.8 \\
\hline $\mathrm{P}-\mathrm{Ge}-\mathrm{C}\left({ }^{\circ}\right)$ & 30.709 & 123.202 & Ge-C-P $\left(^{\circ}\right)$ & 158.911 & 79.415 \\
\hline Molecule & VIII-Me $_{3}$ & IX-Me & & & \\
\hline Relative energy & 89.55 & 31.37 & & & \\
\hline $\mathrm{Ge}-\mathrm{C}(\mathrm{pm})$ & 175.2 & 202.6 & & & \\
\hline $\mathrm{P}-\mathrm{Ge}(\mathrm{pm})$ & 240.7 & 202.9 & & & \\
\hline $\mathrm{P}-\mathrm{Ge}-\mathrm{C}\left({ }^{\circ}\right)$ & 105.366 & 179.999 & & & \\
\hline
\end{tabular}

It can be noticed that the most stable isomer is isomer II, but that the more stericaly hindered $\mathrm{MeP}=\mathrm{C}=\mathrm{GeMe}_{2} \mathbf{I}-\mathrm{Me}$ is more stable by comparison with the $\mathrm{HP}=\mathrm{C}=\mathrm{GeH}_{2}$ analogue, the energy difference between I and IX being $195.27 \mathrm{~kJ} / \mathrm{mol}$ for the former and $105.97 \mathrm{~kJ} / \mathrm{mol}$ for the latter. This is in line with the experimental observation that increasing hindrance around the $\mathrm{Ge}=\mathrm{C}=\mathrm{P}$ unit by using very bulky groups (like Mes, Tip, $t \mathrm{Bu}$ or Mes*) affords longer lifetime to allow the isolation of phosphagermaallenes [9].

There are no significant changes in the form of the frontier orbitals going from $\mathrm{H}_{2} \mathrm{Ge}=\mathrm{C}=\mathrm{PH}$ to $\mathrm{Me}_{2} \mathrm{Ge}=\mathrm{C}=\mathrm{PMe}$ proving that the basic electronic effects are those determined by the $\mathrm{H}_{2} \mathrm{GeCPH}$ skeleton

\section{II.2. Investigations of model phosphagermaallenes isomers through higher level correlation methods}

To improve the treatment of electron correlation, and to check the validity of the DFT treatment geometry optimizations have also been run at the CCSD/6-31G(d, p) [19-22] and MP4(SDQ)/6$31 \mathrm{G}(\mathrm{d}, \mathrm{p})$ [23] levels of the theory using Gaussian 98 [24]. The calculated energies are given in Table 3.

Table 3. Calculated CCSD/6-31G(d, p) and $M P 4 / 6-31 G(d, p)$ energies (a.u.) for the phosphagermaallene isomers I-IX

\begin{tabular}{llllll}
\hline Molecule & I & I $_{\text {triplet }}$ & II & III & IV \\
\hline CCSD/6-31G(d,p) & -2453.83907 & -2453.72529 & -2453.89820 & -2453.86917 & -2453.86749 \\
MP4/6-31G(d,p) & -2453.83852 & -2453.72482 & -2453.89877 & -2453.86794 & -2453.86626 \\
\hline Molecule & V & VI & VII & VIII & IX \\
\hline CCSD/6-31G(d,p) & -2453.86956 & -2453.81166 & -2453.88406 & -2453.82308 & -2453.91630 \\
MP4/6-31G(d,p) & -2453.86851 & -2453.80834 & -2453.88359 & -2453.81987 & -2453.91620 \\
\hline
\end{tabular}

The correlation methods give similar geometries and relative energies (see the Supplementary Information) to those found by DFT, as isomer IX is calculated to be the most stable one. However the cyclic structures have lower relative energies than those calculated at the B3LYP level. It is worth to note here that the DFT methods (particularly B3LYP also) predict lower 
energy for $\mathrm{H}_{2} \mathrm{C}=\mathrm{C}=\mathrm{CH}_{2}$ than for the propyne isomer $\left(\mathrm{HC} \equiv \mathrm{C}-\mathrm{CH}_{3}[25,26]\right.$ in contrast with experiment and results obtained at explicitly correlated methods (MP2 and CCSD(T)) with various basis sets [26]. The present B3LYP calculations on the heavier allene type systems supported by the results at the CCSD and MP4 levels increase the reliability of the DFT-B3LYP method in describing the properties of such systems.

\section{II.3. The influence of substituents on $\mathrm{Ge}$ - a measure for the stability of the $\mathrm{P}=\mathrm{C}=\mathrm{Ge}$ unit}

The role of electronic effects of substituents in stabilizing systems containing the $\mathrm{P}=\mathrm{C}=\mathrm{Ge}$ unit has not been assessed so far. If voluminous ligands (which block or decrease the reactivity of the protected double bond) could be replaced by smaller substituents inducing electronic stabilization (i..e larger HOMO-LUMO gaps) the properties of this allenic core could be (at least in theory) tuned by using different types of substituents.

This study aims to identify the influence that the nature (electron withdrawing or releasing) of several substituents would have on the strength of the $\mathrm{C}=\mathrm{Ge}$ bond in the $\mathrm{P}=\mathrm{C}=\mathrm{Ge}$ unit. The analysis is based on a treatment using the NBO 3.1 program [27] incorporated in Gaussian 98.

The $\mathrm{C}=\mathrm{Ge}$ and $\mathrm{C}=\mathrm{P}$ bond lengths found for $\mathrm{H}_{2} \mathrm{Ge}=\mathrm{C}=\mathrm{PH}$ by a B3LYP/6-311G(d,p) geometry optimization are $178 \mathrm{pm}$ and $1.64 \mathrm{pm}$, respectively. These values are in agreement with experimental data: a $178 \mathrm{pm}$ bond length was reported for $\mathrm{Ge}=\mathrm{C}$ in a 1-germaallene [28]. The $\mathrm{P}=\mathrm{C}$ bond in phosphaallenes is usually slightly shorter than $164 \mathrm{pm}$, as expected from the $s p$ hybridization of the $\mathrm{C}$ atom [2]. The $\mathrm{P}=\mathrm{C}=\mathrm{Ge}$ unit in the model compound is not linear, as it is the case for carbon-allenic structures; the $\mathrm{GeCP}$ angle has a value of $160.4^{\circ}$. The $\mathrm{NBO}$ analysis performed on the optimized structure I indicates a $s p$ hybridization for the carbon atom, together with the expected $s p^{2}$ hybridization for the germanium. The reason for the calculated deviation from linearity seems to be an hyperconjugation effect involving donation of electron density from the phosphorus lone pair to the antibond orbital localized on the Ge-C bond (Figure 3a). This is shown by the second order perturbation analysis of the Fock matrix in the NBO basis (see the relevent part of the output file in the Supplemental Information Section). Such interactions can also account for a smaller bond order than 2, as the calculated Wiberg bond index [29] for the $\mathrm{Ge}=\mathrm{C}$ bond is 1.6575 . Figure $3 \mathrm{~b}, \mathrm{c}$ shows the shape of the lone pair orbital (LP) on the phosphorus and the $\sigma$-antibond orbital on the Ge-C atom. Note that the LP bearing orbital matches the phase of $\sigma$-antibond (red coloured in Figure 3c), and this interaction is enhanced by the bending of the PCGe skeleton. 
Figure 3. Lone-pair- $\sigma^{*}$ hyperconjugation in the case of the $\mathrm{P}=\mathrm{C}=\mathrm{Ge}$ unit (a) between the $\mathrm{P}$ lone pair (b) and the $\sigma^{*}$ orbital on the $\mathrm{Ge}-\mathrm{C}$ bond $(\mathbf{c})$ in the case of $\mathrm{HP}=\mathrm{C}=\mathrm{GeH}_{2}$

Another significant interaction with the same effect in the decrease of the Ge-C bond order is a charge transfer from a P-H bonding orbital to the $\pi$-symmetry antibond orbital on the Ge-C bond (Figure 4a).

Figure 4. $\sigma-\pi^{*}$ interaction (a) between the P-H bond orbital (b) and the Ge-C antibonding NB orbital (c) in the model phosphagermaallene $\mathrm{HP}=\mathrm{C}=\mathrm{GeH}_{2}$

The effect that different substituents containing group 13 to 17 elements on the germanium atom would have on the bond order of the $\mathrm{Ge}-\mathrm{C}$ bond in phosphagermaallenes has been investigated by B3LYP/6-311G(d, p) calculations on the model compounds shown in Table 5.

Table 5. B3LYP/6-311G(d,p)geometrical data and Wiberg bond indexes for model phosphagermaallenes

\begin{tabular}{|c|c|c|c|c|}
\hline Molecule & $\mathrm{HP}=\mathrm{C}=\mathrm{Ge}\left(\mathrm{BH}_{2}\right) \mathrm{H}$ & $\mathrm{HP}=\mathrm{C}=\mathrm{Ge}\left(\mathrm{BH}_{2}\right)_{2}$ & $\mathrm{HP}=\mathrm{C}=\mathrm{Ge}\left(\mathrm{CH}_{3}\right) \mathrm{H}$ & $\mathrm{HP}=\mathrm{C}=\mathrm{Ge}\left(\mathrm{CH}_{3}\right)_{2}$ \\
\hline $\mathrm{Ge}-\mathrm{C}(\mathrm{pm})$ & 180.1 & 182.5 & 177.9 & 177.9 \\
\hline C-P (pm) & 163.5 & 163.6 & 164.1 & 164.2 \\
\hline $\mathrm{P}-\mathrm{C}-\mathrm{Ge}\left({ }^{\circ}\right)$ & 170.8 & 171.9 & 160.7 & 160.5 \\
\hline $\mathrm{Ge}-\mathrm{C}$ bond order & 1.52 & 1.43 & 1.62 & 1.57 \\
\hline Molecule & $\mathrm{HP}=\mathrm{C}=\mathrm{Ge}\left(\mathrm{SiH}_{3}\right) \mathrm{H}$ & $\mathrm{HP}=\mathrm{C}=\mathrm{Ge}\left(\mathrm{SiH}_{3}\right)_{2}$ & $\mathrm{HP}=\mathrm{C}=\mathrm{Ge}\left(\mathrm{NH}_{2}\right) \mathrm{H}$ & $\mathrm{HP}=\mathrm{C}=\mathrm{Ge}\left(\mathrm{NH}_{2}\right)_{2}$ \\
\hline $\mathrm{Ge}-\mathrm{C}(\mathrm{pm})$ & 178.5 & 178.9 & 179.6 & 179.7 \\
\hline C-P (pm) & 164.0 & 164.2 & 164.7 & 164.3 \\
\hline $\mathrm{P}-\mathrm{C}-\mathrm{Ge}\left({ }^{\circ}\right)$ & 163.5 & 166.1 & 147.0 & 155.9 \\
\hline Ge-C bond order & 1.64 & 1.64 & 1.50 & 1.40 \\
\hline Molecule & $\mathrm{HP}=\mathrm{C}=\mathrm{Ge}(\mathrm{OMe}) \mathrm{H}$ & $\mathrm{HP}=\mathrm{C}=\mathrm{Ge}(\mathrm{OMe})_{2}$ & $\mathrm{HP}=\mathrm{C}=\mathrm{GeFH}$ & $\mathrm{HP}=\mathrm{C}=\mathrm{GeF}_{2}$ \\
\hline $\mathrm{Ge}-\mathrm{C}(\mathrm{pm})$ & 163.8 & 182.9 & 179.0 & 185.9 \\
\hline C-P (pm) & 178.1 & 164.7 & 168.3 & 164.3 \\
\hline $\mathrm{P}-\mathrm{C}-\mathrm{Ge}\left({ }^{\circ}\right)$ & 167.0 & 147.6 & 162.7 & 147.1 \\
\hline Ge-C bond order & 1.51 & 1.36 & 1.52 & 1.34 \\
\hline
\end{tabular}

The largest bond order is calculated for substituents containing group 14 elements, like $\mathrm{CH}_{3}$ and $\mathrm{SiH}_{3}$. The calculation was also carried out for a phosphagermaallene bearing a $\mathrm{SiMe}_{3}$ group on the germanium atom to check if the $\mathrm{Si}-\mathrm{H}$ bond is not the one determining the higher bond order through stabilizing hyperconjugation effects towards the $\mathrm{Ge}=\mathrm{C}$ unit, and also because $\mathrm{SiH}_{3}$ would make a poor experimental choice. The results for $\mathrm{HP}=\mathrm{C}=\mathrm{Ge}\left(\mathrm{SiMe}_{3}\right)_{2}$ were similar to those obtained for $\mathrm{HP}=\mathrm{C}=\mathrm{Ge}\left(\mathrm{SH}_{3}\right)_{2}$ with a calculated Wiberg bond order of 1.6396. The most 
important interaction that leads to the decrease in the $\mathrm{Ge}=\mathrm{C}$ bond strength remains the donation of electron density from the $\mathrm{P}$ lone pair to the antibond orbital oriented on the $\mathrm{Ge}-\mathrm{C}$ bond.

The low bond order in the case of the model compound $\mathrm{HP}=\mathrm{C}=\mathrm{GeF}_{2}$ is explained by supplementary interactions due to the presence of the fluorine atom, bearing electron lone pairs (Figure 5).

Figure 5. Non-bonding orbitals involved in hyperconjugation leading to $\mathrm{Ge}=\mathrm{C}$ destabilization in $\mathrm{HP}=\mathrm{C}=\mathrm{GeF}_{2}$ (a) lone pair on $\left.\mathrm{F}, \mathrm{b}\right) \pi^{*}$ orbital on the Ge-C bond)

The NBO analysis shows a strong delocalization the lone pair oriented perpendicular to the Ge-F bond to the $\pi^{*}$ orbital on the Ge-C bond and both fluorine atoms display this type of interaction. Figure 5 shows the shape of the orbitals involved. The other lone pair is oriented perpendicular to the $\pi^{*}$ orbital and cannot contribute to the mentioned hyperconjugative effect.

\section{Outlook}

The $\mathrm{Ge}=\mathrm{C}$ bond in phosphagermaallenes is weakened by a hyperconjugative effect directed from the $\mathrm{P}$ lone pair to the Ge-C bonding orbital. Substituents with atoms bearing lone pairs or vacant $p$ orbitals induce other types of charge transfer which also result in the weakening of the $\mathrm{Ge}=\mathrm{C}$ bond order, while groups containing group 14 elements like Si and C are found to be "inert" and such substituents might stabilize the PCGe skeleton, still leaving access to the functionality of the double bonds.

\section{Acknowledgments}

The authors are grateful to Professor Romuald Poteau (Université Paul Sabatier, Toulouse) for helpful discussions. Financial support from the French Ministery of Foreign Affairs (ECO-NET program $\mathrm{n}^{\circ}$ 18824SD) is acknowledged. We thank Dr. Joaquin Barosso-Flores for useful discussion on the NBO analysis.

Supplementary information on the MP4 and CCSD optimized geometries, geometrical data relative energies and results on the second order perturbation NBO analysis is available at or on the request from the authors. 


\section{References:}

1. A. G. Brook, F. Abdesaken, B. Gutekunst, G. Gutekunst, R. K. Kallury, J. Chem. Soc., Chem. Commun., 191, (1981).

2. J. Escudié, H. Ranaivonjatovo, and L. Rigon, Chem. Rev., 100, 3639 (2000).

3. J. Escudié, H. Ranaivonjatovo, M. Bouslikhane, Y. El Harouch, L. Baiget, G. Cretiu Nemes, Russ. Chem. Bull., 53, 1020 (2004).

4. J. Escudié, H. Ranaivonjatovo, Organometallics, 26, 1542 (2007).

5. M. A. Chaubon, B. Dittrich, J. Escudie, H. Ramdane, H. Ranaivonjatovo, J. Satge, Synth. React. Inorg. Met-Org. Chem., 27, 519 (1997).

6. G. Nemes, J. Escudie, I. Silaghi-Dumitrescu, H. Ranaivonjatovo, L. Silaghi-Dumitrescu, H. Gornitzka, Organometallics, 26, 5136 (2007).

7. P. M. Petrar, G. Nemes, I. Silaghi-Dumitrescu, H. Ranaivonjatovo, H. Gornitzka, J. Escudié, Chem. Commun., 40, 4149 (2007).

8. H. Ramdane, H.Ranaivonjatovo, J. Escudié, S. Mathieu, and N. Knouzzi, Organometallics, 15, 3070 (1996).

9. Y. El Harouch, H. Gornitzka, H. Ranaivonjatovo, J. Escudié, J. Organomet. Chem., 643-644, 202 (2002).

10. A.D. Becke, J.Chem.Phys., 98, 5648 (1993).

11. C. Lee, W. Yang, and R.G. Parr, Phys. Rev. B, 37, 785 (1988).

12. S. H. Vosko, L. Wilk, and M. Nusair, Can. J. Phys., 58, 1200 (1980).

13. P. J. Stephens, F. J. Devlin, C. F. Chabalowski, and M. J. Frisch, J. Phys. Chem., 98, 11623 (1994).

14. Wavefunction Inc.18401 Von Karman Avenue, Suite 370 Irvine, CA 92612.

15. H. Basch, Inorg. Chim. Acta, 252, 265 (1996).

16. C.L. Chin-Hung Lai, M. Su, and S. Y. Chu, J. Phys. Chem. A, 106, 575 (2002).

17. A. H. Cowley, S. W. Hall, C. M. Nunn, and J. M. Power, Chem. Commun, 753 (1988).

18. Z. Rappoport, editor, The Chemistry of Organic Germanium, Tin and Lead Compounds, 2 vols., (John Wiley \& Sons, 2002).

19. J. Cizek, Adv. Chem. Phys., 14, 35 (1969).

20. G. D. Purvis and R. J. Bartlett, J. Chem. Phys., 76, 1910 (1982).

21.G. E. Scuseria, C. L. Janssen, and H. F. Schaefer III; J. Chem. Phys., 89, 7382 (1988).

22. G. E Scuseria, H. F. Schaefer III, J. Chem. Phys., 90, 3700 (1989).

23 R. Krishnan, J. A. Pople, Int. J. Quant. Chem., 14, 91 (1978).

24. Gaussian 98, Revision A.6, M. J. Frisch, G. W. Trucks, H. B. Schlegel, G. E. Scuseria, M. A. Robb, J. R. Cheeseman, V. G. Zakrzewski, J. A. Montgomery, Jr., R. E. Stratmann, J. C. Burant, S. Dapprich, J. M. Millam, A. D. Daniels, K. N. Kudin, M. C. Strain, O. Farkas, J. Tomasi, V. Barone, M. Cossi, R. Cammi, B. Mennucci, C. Pomelli, C. Adamo, S. Clifford, J. Ochterski, G. A. Petersson, P. Y. Ayala, Q. Cui, K. Morokuma, D. K. Malick, A. D. Rabuck, K. Raghavachari, J. B. Foresman, J. Cioslowski, J. V. Ortiz, B. B. Stefanov, G. Liu, A. Liashenko, P. Piskorz, I. Komaromi, R. Gomperts, R. L. Martin, D. J. Fox, T. Keith, M. A. Al-Laham, C. Y. Peng, A. Nanayakkara, C. Gonzalez, M. Challacombe, P. M. W. Gill, B. Johnson, W. Chen, M. W. Wong, J. L. Andres, C. Gonzalez, M. Head-Gordon, E. S. Replogle, and J. A. Pople, Gaussian, Inc., Pittsburgh PA, 1998.

25. R. Kakkar, R. Garg, P. Chadha, J. Mol. Struct. (Theochem), 617, 141 (2002).

26. H. L. Woodcock, H. F. Schaefer, and P. R. Schreiner, J. Phys. Chem. A, 106, 11923 (2002).

27. NBO Version 3.1, E. D. Glendening, A. E. Reed, J. E. Carpenter, and F. Weinhold.

28. B. E. Eichler, D. R. Powell, and R. West, Organometallics, 17, 2147 (1998).

29. K.B. Wiberg, Tetrahedron, 24, 1083 (1968). 


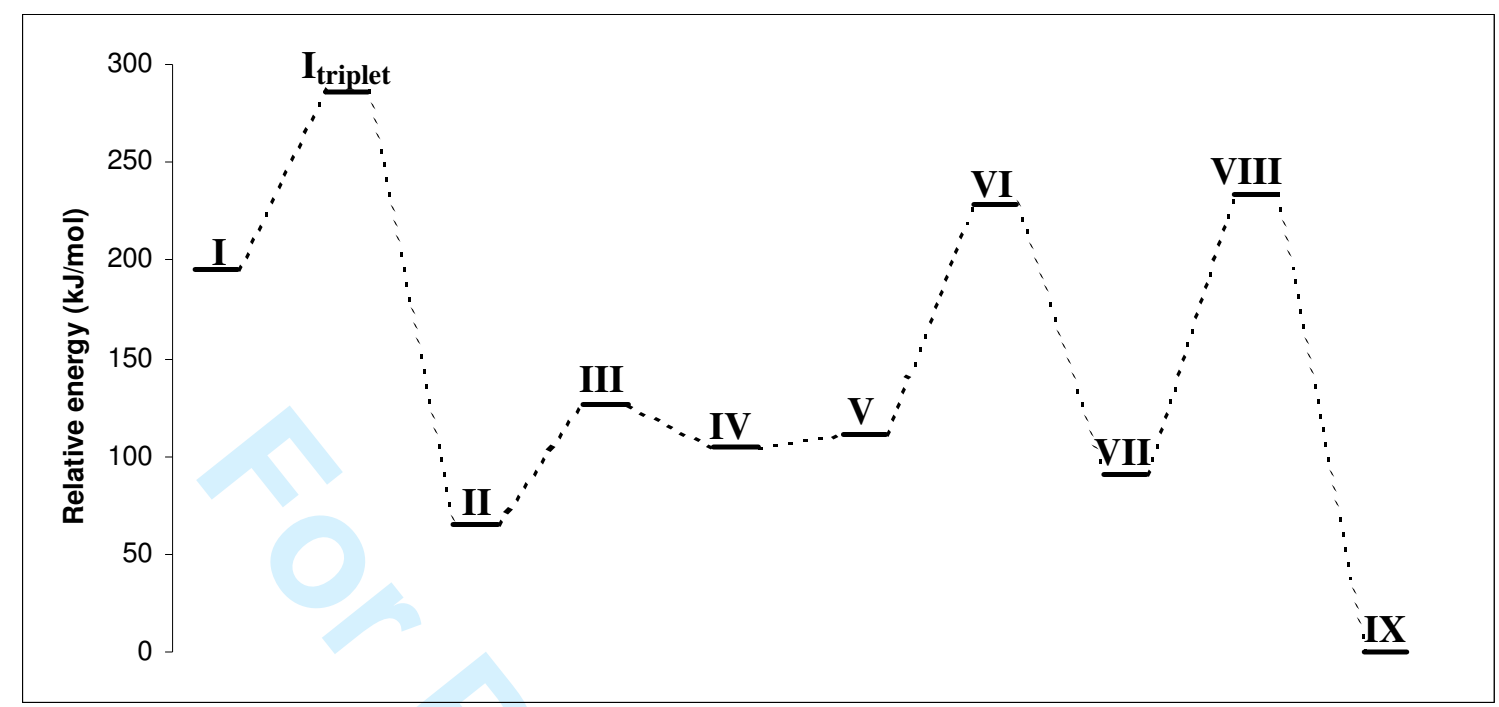

Figure 1. Relative energies in $\mathrm{kJ} / \mathrm{mol}$ (compared to the series minimum $\mathbf{I X}$ ) of $\mathrm{CH}_{3} \mathrm{GeP}$ isomers

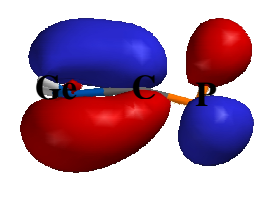

a

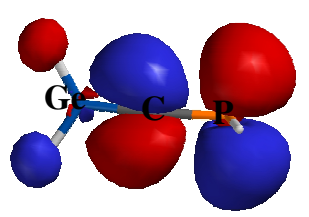

b

Figure 2. $\mathrm{HOMO}$ (a) and LUMO (b) orbitals of $\mathrm{HP}=\mathrm{C}=\mathrm{GeH}_{2} \mathbf{I}$ 
a

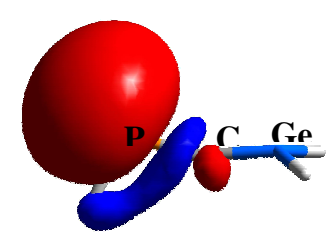

b

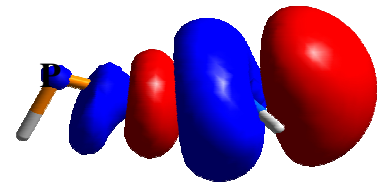

c

Figure 3. Lone-pair- $\sigma^{*}$ hyperconjugation in the case of the $\mathrm{P}=\mathrm{C}=\mathrm{Ge}$ unit (a) between the $\mathrm{P}$ lone pair (b) and the $\sigma^{*}$ orbital on the $\mathrm{Ge}-\mathrm{C}$ bond $(\mathbf{c})$ in the case of $\mathrm{HP}=\mathrm{C}=\mathrm{GeH}_{2}$

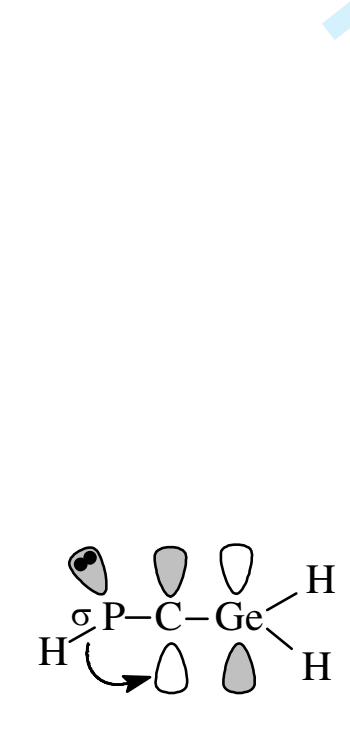

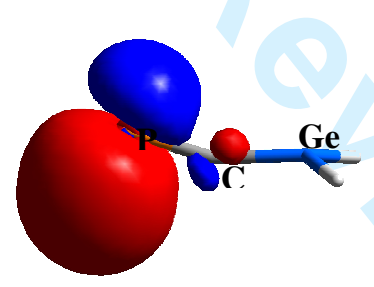

b

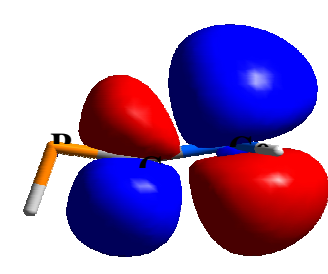

c

Figure 4. $\sigma-\pi *$ interaction (a) between the P-H bond orbital (b) and the Ge-C antibonding NB orbital (c) in the model phosphagermaallene $\mathrm{HP}=\mathrm{C}=\mathrm{GeH}_{2}$ 


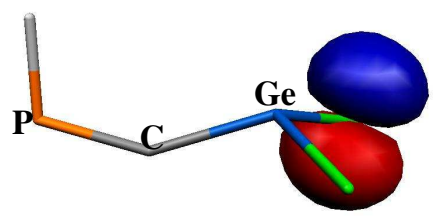

a

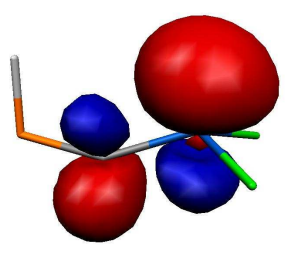

b

Figure 5. Non-bonding orbitals involved in hyperconjugation leading to $\mathrm{Ge}=\mathrm{C}$ destabilization in $\mathrm{HP}=\mathrm{C}=\mathrm{GeF}_{2}$ (a) lone pair on $\mathrm{F}$, (b) $\pi^{*}$ orbital on the Ge-C bond 


\title{
An Insight into the Structure of Model Germaphosphaallenes
}

\author{
P. M. Petrar ${ }^{\mathrm{a}, \mathrm{b}}$, G. Nemes ${ }^{\mathrm{a}}$, I. Silaghi-Dumitrescu ${ }^{1 \mathrm{a}}$, J. Escudié $^{\mathrm{b}}$, H. Ranaivonjatovo ${ }^{\mathrm{b}}$ \\ ${ }^{a}$ Babes-Bolyai University, Cluj-Napoca, Romania $;{ }^{b}$ Hétérochimie Fondamentale et Appliquée Université \\ Paul Sabatier, Toulouse, France
}

\section{Supplementary information:}

Table S1. Calculated CCSD/6-31G(d,p) energies and geometrical parameters for $\mathrm{HP}=\mathrm{C}=\mathrm{GeH}_{2}$ isomers

Table S2. Calculated MP4(SDQ)/6-31G(d,p) energies and geometrical parameters for $\mathrm{HP}=\mathrm{C}=\mathrm{GeH}_{2}$ isomers

Figure S1. Variation of the relative energies calculated with CCSD/6-31G(d, p) and MP4/6$31 \mathrm{G}(\mathrm{d}, \mathrm{p})$ for isomers I-IX

Table S4. Calculated B3LYP/6-31G(d,p) energies for isomers I-IX

Table S5. Calculated B3LYP/6-31G(d,p) energies for isomers I-Me-IX-Me

Table S6. Excerpt from the second order perturbation theory analysis of Fock Matrix in NBO basis for (a) $\mathrm{HP}=\mathrm{C}=\mathrm{GeH}_{2}$ and (b) $\mathrm{HP}=\mathrm{C}=\mathrm{GeF}_{2}$

\footnotetext{
${ }^{1}$ Corresponding author. Email : isi@chem.ubbcluj.ro
} 
Table S1. Calculated CCSD/6-31G(d,p) energies and geometrical parameters for $\mathrm{HP}=\mathrm{C}=\mathrm{GeH}_{2}$ isomers

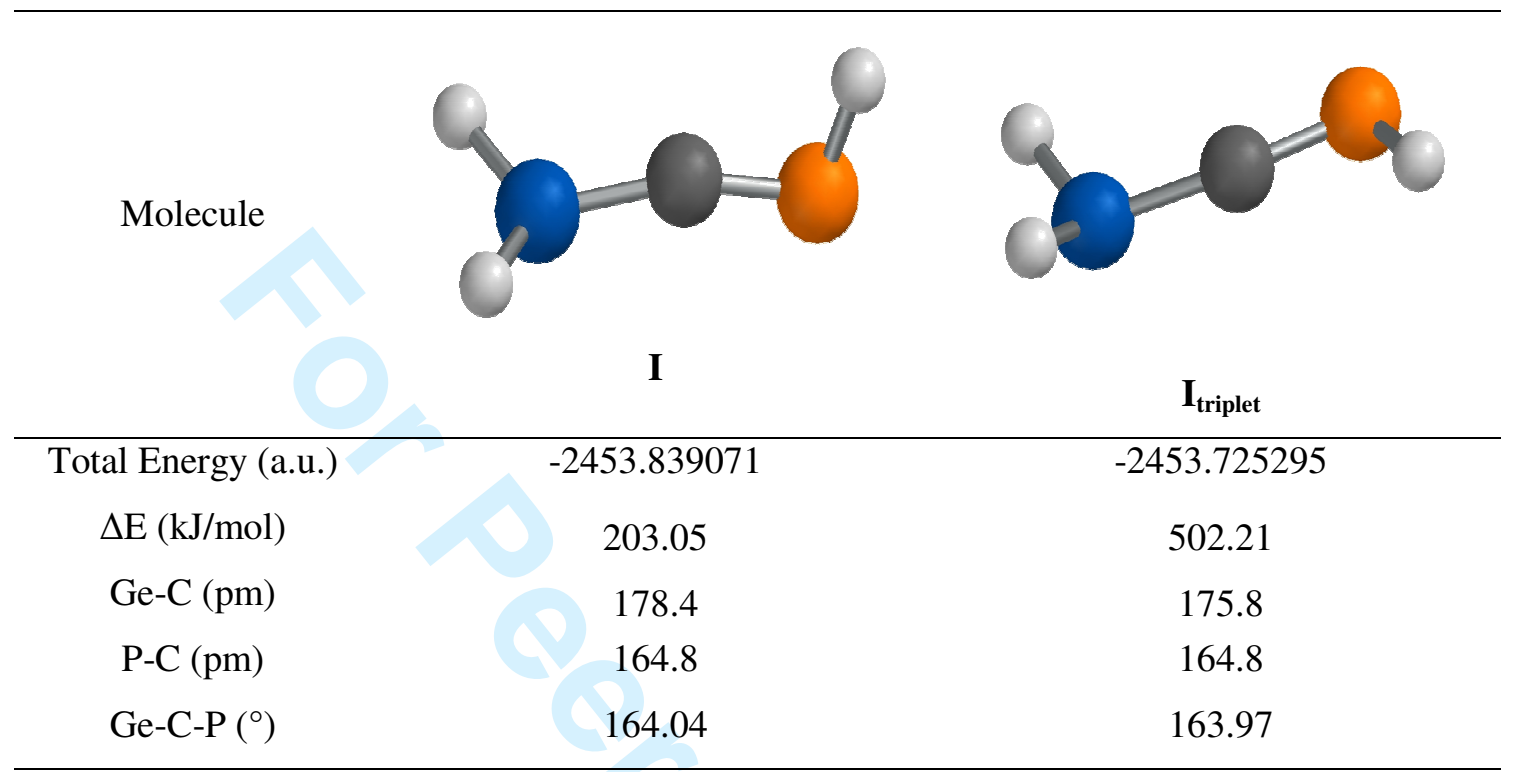

Molecule

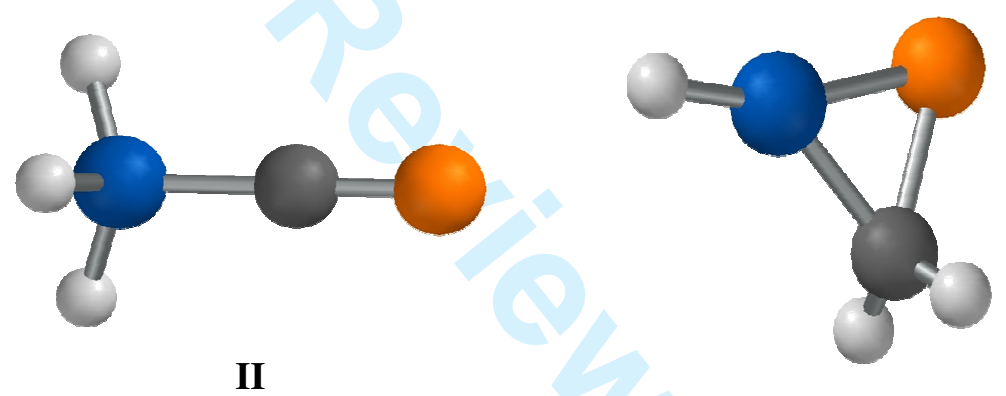

III

\begin{tabular}{ccc}
\hline Total Energy (a.u.) & -2453.898196 & -2453.869169 \\
$\Delta \mathrm{E}(\mathrm{kJ} / \mathrm{mol})$ & 47.60 & 123.94 \\
$\mathrm{Ge}-\mathrm{C}(\mathrm{pm})$ & 191.7 & 194.1 \\
$\mathrm{P}-\mathrm{C}(\mathrm{pm})$ & 155.6 & 197.2 \\
$\mathrm{Ge}-\mathrm{C}-\mathrm{P}\left(^{\circ}\right)$ & 179.84 & 65.30 \\
\hline
\end{tabular}

URL: http://mc.manuscriptcentral.com/tandf/tmph 
Molecule

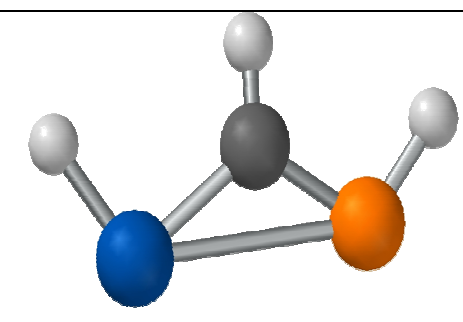

IV

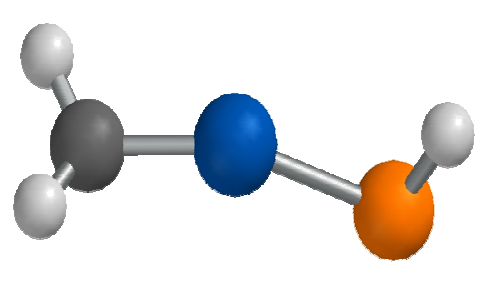

V

\begin{tabular}{ccc}
\hline Total Energy (a.u. $)$ & -2453.867485 & -2453.869561 \\
$\Delta \mathrm{E}(\mathrm{kJ} / \mathrm{mol})$ & 126.12 & 122.89 \\
$\mathrm{Ge}-\mathrm{C}(\mathrm{pm})$ & 197.2 & 179.2 \\
$\mathrm{P}-\mathrm{Ge}(\mathrm{pm})$ & 310.5 & 214.0 \\
$\mathrm{P}-\mathrm{Ge}-\mathrm{C}\left(^{\circ}\right)$ & 29.23 & 157.82 \\
\hline
\end{tabular}

Molecule
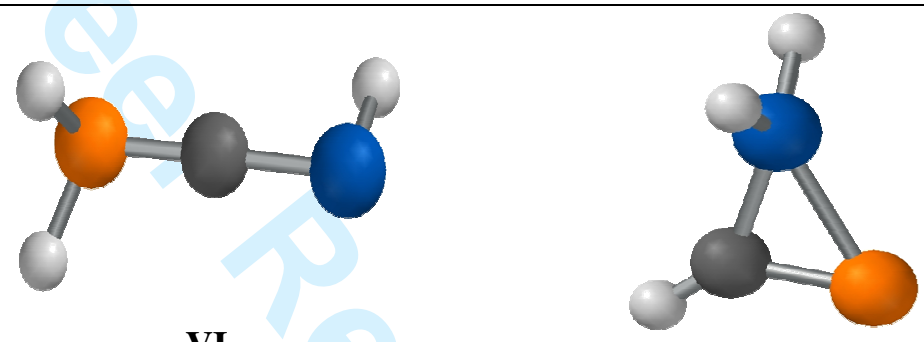

VI

VII

\begin{tabular}{ccr}
\hline Total Energy (a.u.) & -2453.811658 & -2453.88405 \\
$\Delta \mathrm{E}(\mathrm{kJ} / \mathrm{mol})$ & 275.16 & 84.76 \\
$\mathrm{Ge}-\mathrm{C}(\mathrm{pm})$ & 177.8 & 191.5 \\
$\mathrm{P}-\mathrm{C}(\mathrm{pm})$ & 171.7 & 168.6 \\
$\mathrm{Ge}-\mathrm{C}-\mathrm{P}\left(^{\circ}\right)$ & 170.35 & 79.87
\end{tabular}

Molecule

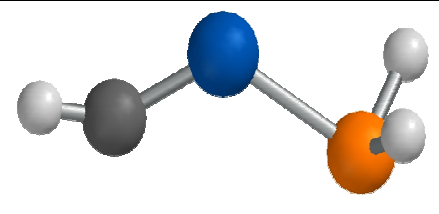

VIII

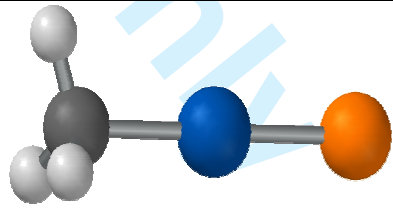

IX

\begin{tabular}{ccc}
\hline Total Energy (a.u.) & -2453.823081 & -2453.91631 \\
$\Delta \mathrm{E}(\mathrm{kJ} / \mathrm{mol})$ & 245.12 & 0.00 \\
$\mathrm{Ge}-\mathrm{C}(\mathrm{pm})$ & 172.3 & 195.3 \\
$\mathrm{P}-\mathrm{Ge}(\mathrm{pm})$ & 232.8 & 202.8 \\
$\mathrm{P}-\mathrm{Ge}-\mathrm{C}\left({ }^{\circ}\right)$ & 129.16 & 179.92
\end{tabular}


Table S2. Calculated MP4(SDQ)/6-31G(d,p) energies and geometrical parameters for $\mathrm{HP}=\mathrm{C}=\mathrm{GeH}_{2}$ isomers

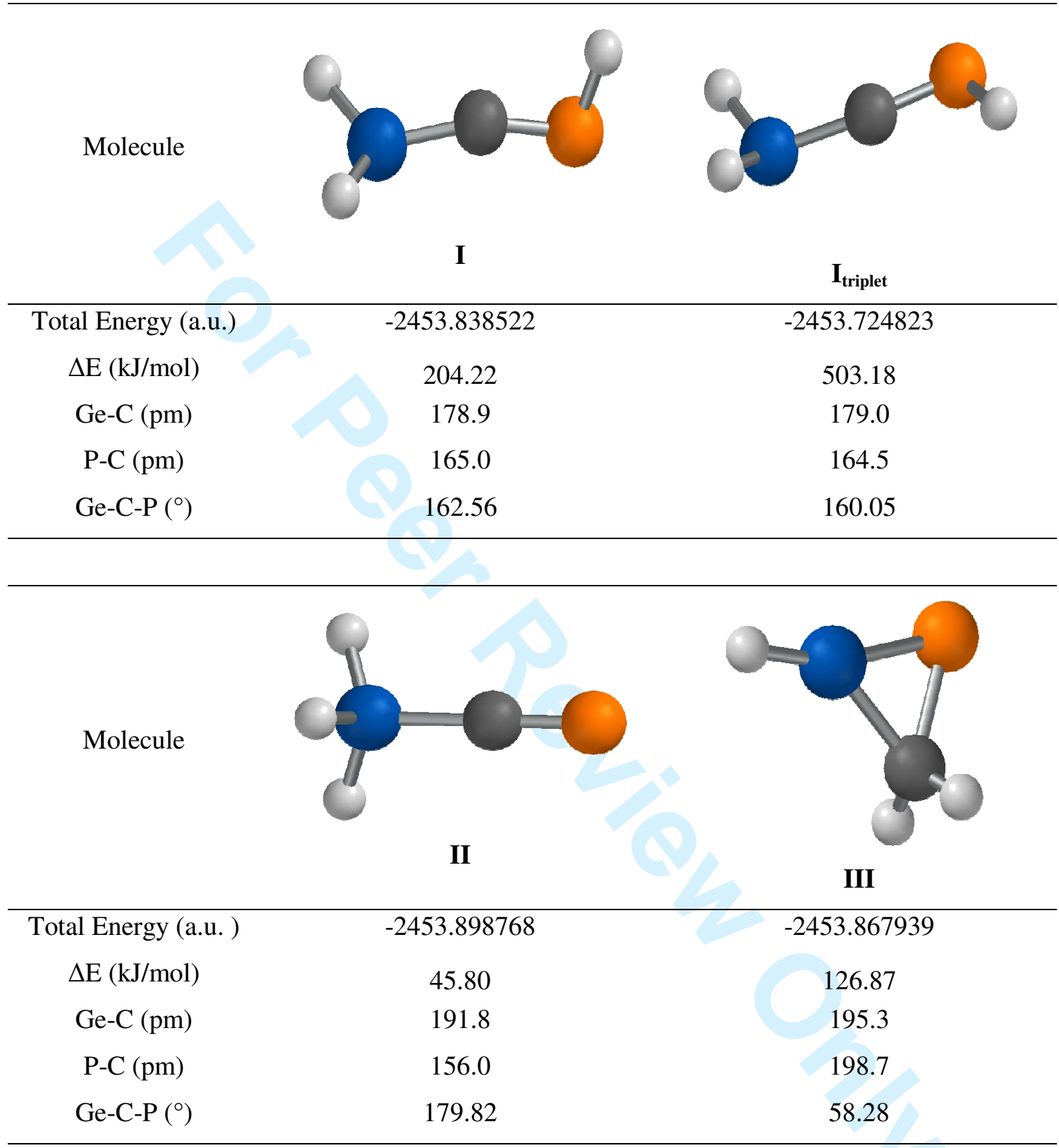


Molecule

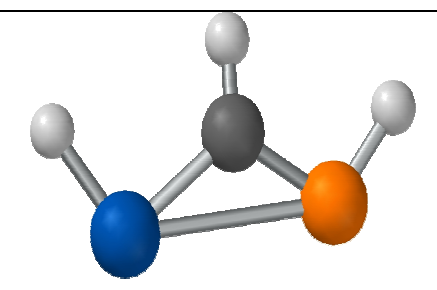

IV

\begin{tabular}{ccc}
\hline Total Energy (a.u. $)$ & -2453.866262 & -2453.868517 \\
$\Delta \mathrm{E}(\mathrm{kJ} / \mathrm{mol})$ & 131.27 & 125.36 \\
$\mathrm{Ge}-\mathrm{C}(\mathrm{pm})$ & 197.1 & 179.2 \\
$\mathrm{P}-\mathrm{Ge}(\mathrm{pm})$ & 309.9 & 213.6 \\
P-Ge-C $\left(^{\circ}\right)$ & 29.40 & 156.79 \\
\hline
\end{tabular}

Molecule

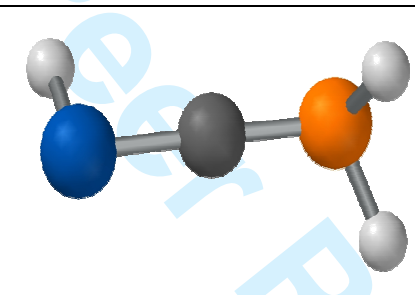

VI

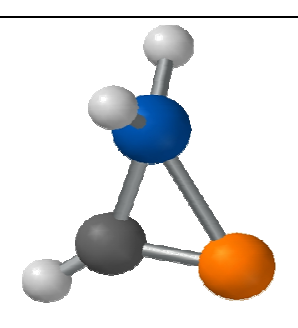

VII

\begin{tabular}{ccc}
\hline Total Energy (a.u. $)$ & -2453.808344 & -2453.88359 \\
$\Delta \mathrm{E}(\mathrm{kJ} / \mathrm{mol})$ & 283.58 & 85.73 \\
$\mathrm{Ge}-\mathrm{C}(\mathrm{pm})$ & 180.1 & 191.3 \\
$\mathrm{P}-\mathrm{C}(\mathrm{pm})$ & 1.666 & 168.7 \\
$\mathrm{Ge}-\mathrm{C}-\mathrm{P}\left({ }^{\circ}\right)$ & 177.84 & 79.82 \\
\hline
\end{tabular}

Molecule

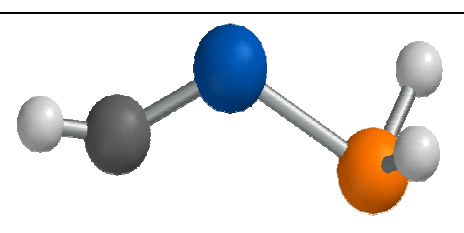

VIII

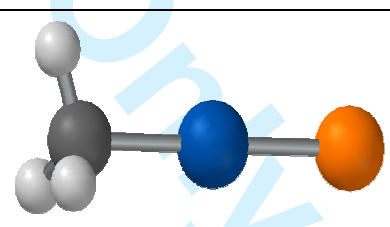

IX

\begin{tabular}{ccc}
\hline Total Energy (a.u.) & -2453.819879 & -2453.916201 \\
$\Delta \mathrm{E}(\mathrm{kJ} / \mathrm{mol})$ & 253.24 & 0.00 \\
$\mathrm{Ge}-\mathrm{C}(\mathrm{pm})$ & 172.3 & 195.3 \\
$\mathrm{P}-\mathrm{Ge}(\mathrm{pm})$ & 231.6 & 203.1 \\
P-Ge-C $\left(^{\circ}\right)$ & 136.31 & 179.91 \\
\hline
\end{tabular}

URL: http://mc.manuscriptcentral.com/tandf/tmph 


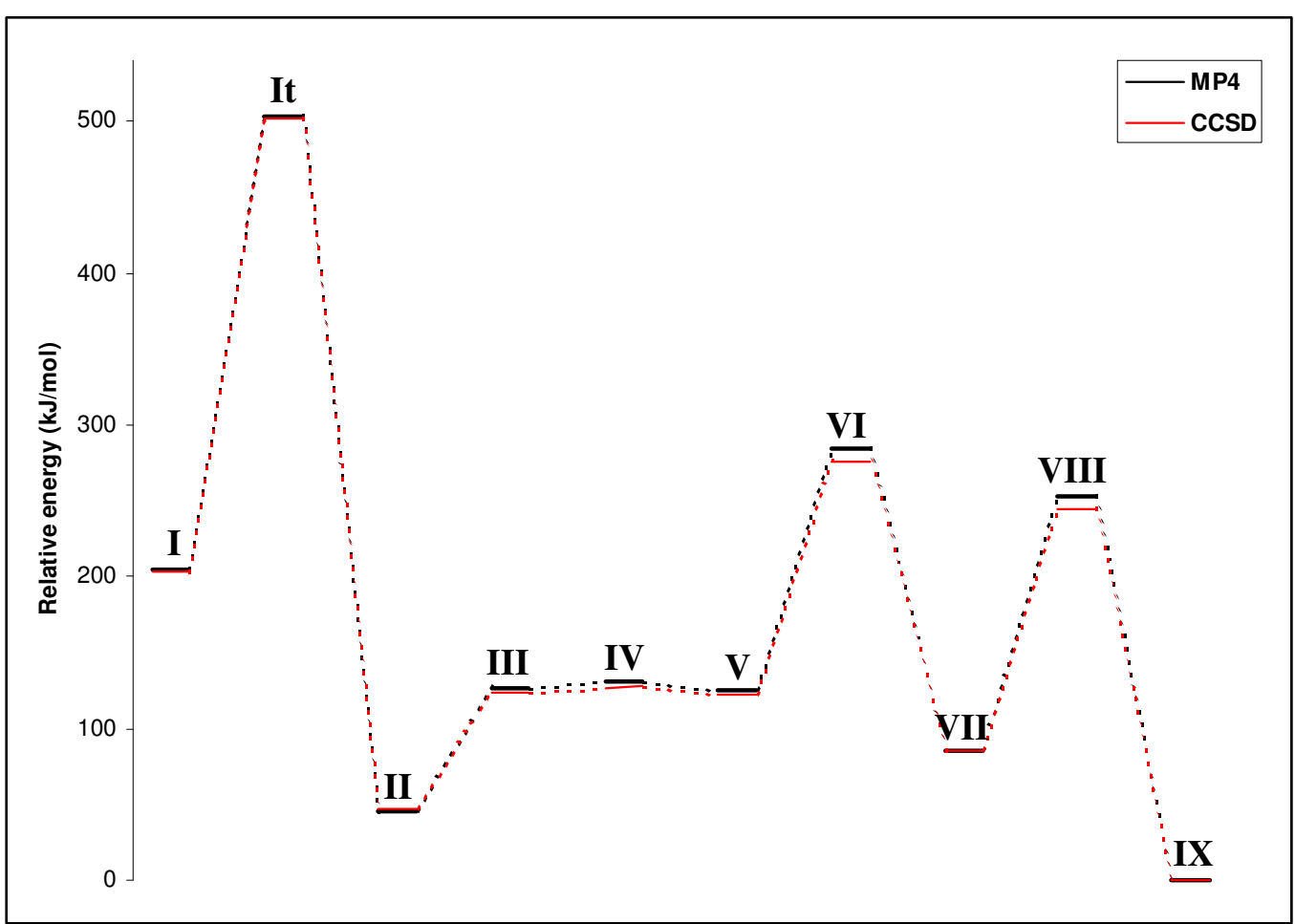

Figure S1. Variation of the relative energies calculated with CCSD/6-31G(d, p) and MP4/6$31 \mathrm{G}(\mathrm{d}, \mathrm{p})$ for isomers I-IX

Table S4. Calculated B3LYP/6-31G(d,p) energies for isomers I-IX

\begin{tabular}{|c|c|}
\hline Molecule & Total energy (a.u.) \\
\hline I & -2457.92568 \\
\hline I $_{\text {t }}$ & -2457.891415 \\
\hline II & -2457.97514 \\
\hline III & -2457.951919 \\
\hline IV & -2457.960168 \\
\hline V & -2457.957917 \\
\hline VI & -2457.913166 \\
\hline VII & -2457.965443 \\
\hline VIII & -2457.911001 \\
\hline IX & $\mathbf{- 2 4 5 8 . 0 0 0 0 0 5}$ \\
\hline
\end{tabular}


Table S5. Calculated B3LYP/6-31G(d,p) energies for isomers I-Me-IX-Me

\begin{tabular}{|c|c|}
\hline Molecule & Total energy (a.u.) \\
\hline I-Me & -2575.906811 \\
\hline It-Me $_{\mathbf{t}}$ & -2575.871256 \\
\hline II-Me & $\mathbf{- 2 5 7 5 . 9 5 9 2 2}$ \\
\hline III-Me & -2575.917116 \\
\hline IV-Me & -2575.930853 \\
\hline V-Me & -2575.91525 \\
\hline VI-Me & -2575.892586 \\
\hline VII-Me & -2575.94575 \\
\hline VIII-Me & -2575.887026 \\
\hline IX-Me & -2575.947134 \\
\hline
\end{tabular}

Table S6. Excerpt from the second order perturbation theory analysis of Fock Matrix in NBO basis for (a) $\mathrm{HP}=\mathrm{C}=\mathrm{GeH}_{2}$ and (b) $\mathrm{HP}=\mathrm{C}=\mathrm{GeF}_{2}$

(a)

\begin{tabular}{|c|c|c|c|c|}
\hline Donor & Acceptor NBO & $\begin{array}{l}E(2) \\
\mathrm{kcal} / \mathrm{mol}\end{array}$ & $\begin{array}{c}E(j)-E(i) \\
\quad \text { a.u. }\end{array}$ & $\begin{array}{c}F(i, j) \\
\text { a.u. }\end{array}$ \\
\hline 1. $\mathrm{B}$ & /104. BI & 7.74 & 0.40 & 0.050 \\
\hline $\mathrm{LP}(1$ & /103. BD*(1) C3-Ge4 & 10.22 & 0.76 & 0.07 \\
\hline
\end{tabular}

(b)

\begin{tabular}{|c|c|c|c|c|}
\hline Donor NBO (i) & Acceptor NBO (j) & $\begin{array}{l}E(2) \\
\mathrm{kcal} / \mathrm{mol}\end{array}$ & $\begin{array}{c}E(j)-E(i) \\
\text { a.u. }\end{array}$ & $\begin{array}{c}F(i, j) \\
\text { a.u. }\end{array}$ \\
\hline 30. LP(1)P3 & $/ 124 . \mathrm{BD} *(1) \mathrm{Ge} 1-\mathrm{C} 2$ & 13.08 & 0.72 & 0.088 \\
\hline 33. LP(3)F5 & /125. BD*(2)Ge1- C2 & 9.83 & 0.30 & 0.05 \\
\hline 36. LP(3)F6 & /125. BD*(2)Ge 1- C2 & 9.83 & 0.30 & 0.0 \\
\hline
\end{tabular}

